\title{
García-Bedoya Maguiña, Carlos (2019). Hermenéutica literaria. Una introducción al análisis de textos narrativos y poéticos. Lima: UNMSM- Cátedra Vallejo.
}

\section{EI penúltimo clásico: pro captu lectoris habent sua fata libelli}

Época de discursos mínimos, tiempo de fragmentarismos y claudicaciones, nuestros estudios literarios no podían ser ajenos al signo de los tiempos. Los grandes compendios, las colecciones enciclopédicas y revisiones severas son afortunados hallazgos casuales. Por esto, la aparición de alguna presa de caza mayor no puede ser sino festejada y aplaudida, con mayor entusiasmo si su origen está marcado por la erudición, rigurosidad y prestancia que da la seguridad del conocimiento. Es casi descubrir el fuego afirmar que el Dr. Carlos García-Bedoya Maguiña es uno de nuestros más notables estudiosos de la literatura. Sanmarquino de siempre, marcado por los grandes maestros que pasaron por los claustros de la ciudad universitaria, ha sabido construir con discreción y envidiable magisterio una obra crítica que debería hacernos sentir orgullo de haber compartido con él nuestro tiempo, avatares y goces literarios. Hermenéutica literaria. Una introducción al análisis de textos narrativos y poéticos es una enorme contribución a los estudios literarios peruanos y un libro que hará perdurar el magisterio del Dr. GarcíaBedoya más allá de nuestro breve paso por la literatura.

Formado alrededor del momento en que se iniciaba la gestación de la crítica literaria latinoamericana, García-Bedoya ha sabido congregar los aportes de diversas generaciones para crear una perspectiva tan respetuosa, caso a caso, de la materia estudiada que resulta ingrato calificar de ecléctica. Desde los últimos frutos de la estilística hasta el pragmatismo literario, pasando por los estructuralismos y postestructuralismos, su paso por las aulas - sea como alumno o destacado profesor - ha sido siempre una oportunidad de enriquecernos con sus aportes certeros y honestos hasta la crudeza, cuando se hace necesario. La oportunidad que se nos presenta al leer Hermenéutica literaria es doble: primero, ser testigos de las huellas de ese tránsito por nuestro arte y, segundo, apreciar la 
claridad y justeza de sus juicios sobre algunos de los textos más célebres de la literatura occidental.

La primera parte del libro se construye como lo hacen las tesis de respeto, una suerte de marco teórico de impensable exclusión. Las definiciones contundentes e iluminadoras son uno de los platos fuertes de García-Bedoya. Desde su perspectiva hermenéutica, que nos hace recordar a los grandes maestros como Spitzer o Ricoeur, opta por una cuestión de principio que no hallamos sino preliminarmente diseñada en los textos fundadores de la hermenéutica: definir las bases de nuestro objeto. Este es un añadido central que permite afirmar que estamos ante un texto concebido como manual de hermenéutica y no solo ante un alarde de manejo teórico e interpretativo. El Dr. García-Bedoya, fiel a su naturaleza de professor, ha construido las bases mismas de este libro pensando en su funcionamiento como clase magistral. Aparecen conceptos esenciales que pocos tienen el coraje de discutir hoy, cuando es más sencillo dar las cosas por asumidas que revisarlas desde una nueva perspectiva; como, por ejemplo, el concepto de género, revisitado desde una perspectiva histórico-funcional (herencia del historicismo de su maestro, el Dr. Antonio Cornejo Polar).

La segunda parte presenta el modelo de análisis: "[Este libro] Busca constituir un esfuerzo de síntesis, que conjugue lo más valioso del aporte de distintas corrientes, por cierto, atendiendo a la necesaria compatibilidad entre elementos de heterogénea procedencia" (p. 86). El método parte del análisis de la explicación (análisis inmanente) y se dirige desde la superficie, el plano de la expresión, hacia el estrato intermedio de la forma del contenido para arribar al estrato profundo o sustancia del contenido. Es decir, recorriendo en sentido inverso el tránsito del autor, García-Bedoya parte de la elocutio para llegar a la inventio a través de la dispositio. Todo esto para culminar en el momento de la comprensión del texto que el autor cataloga como "operación de síntesis trascendente" (p. 90) en la cual bosqueja los puentes entre el texto y la serie histórica.

De esta manera, los capítulos tercero, cuarto, quinto y sexto presentan cada momento del análisis tomando como ejemplo textos canonizados del repertorio 
occidental, en gran medida latinoamericano. No obstante cabe una aclaración: el centro de preocupación del autor es el método. Por ello no trabaja un solo texto desde la superficie hasta llegar al estrato profundo; cada texto será elegido como materia de ejercicio para aclarar el funcionamiento del método. Claro, hay referencias a más de un nivel en alguno de los casos, pero no estamos ante una recopilación de "lecturas literarias", y esto es lo más valioso del libro que nos ocupa. Tenemos ante nuestros ojos a la mente analítica y sensible del gran maestro sanmarquino en funcionamiento.

La generosidad académica es rara avis, cada vez más difícil de hallar. Conocimos esta virtud de primera mano por maestros como Antonio Cornejo Polar, Raúl Bueno, Desiderio Blanco, Carlos Garayar, Tomás Escajadillo... quienes disfrutamos de sus enseñanzas aprendimos algo de "solidaridad académica" y a no olvidar que la raíz de nuestro estudio está en el texto, que es uno y múltiple.

Es imposible no ceder a la nostalgia por los trabajos teóricos fundacionales. $\mathrm{Al}$ revisar Hermenéutica literaria pareciera un libro de otro tiempo, un tributo a los textos clásicos desde una perspectiva integradora e intención universalista contemporánea. Cierto, el libro se construye de la mano de textos canónicos de la literatura occidental hispanoamericana pero no es un libro culturalista, a pesar de la cercanía del autor a los Cultural Studies. Sin embargo, es un sano regreso a los orígenes que va a resultar de utilidad suprema a estudiantes de literatura y todo aquel que se interese por el estudio y comprensión de lo literario. Con honestidad, el autor reconoce el ámbito de aplicación de su método y desnuda su pretensión: "Se trata de un modelo de carácter orientador, que no aspira a sustituir o desplazar a otros modelos interpretativos, sino a guiar un proceso riguroso de aprendizaje introductorio en nuestra disciplina" (p. 15; énfasis agregado). La intención de este texto se desnuda desde el epígrafe: "La capacidad el lector tiene destino propio".

La hermenéutica filológica practicada por García-Bedoya, que entronca con la tradición de la hermenéutica filosófica moderna de Heidegger, continuada por Gadamer y Vattimo, es un paso inmanente que atiende a los mecanismos de 
generación que ponen en movimiento las potencias en el texto sin restricciones de escuela. Con esto quiero dar a entender el carácter primordial e inicial de la aproximación hermenéutica y su potencial registro proteico (y proteínico, por qué no) que le permite apropiarse de todo aporte que ayude a la interpretación del texto, para convertir lo hermético en visible a toda mirada. Este esfuerzo conjunto recorrido de las manos de Proteo y Hermes anota una particularidad esencial en el valioso aporte del Dr. García-Bedoya: lo esencial es el método. Qué sencillo habría sido tomar un texto y aplicar el método hasta agotar los recursos del mismo en él. La perspectiva de este volumen, en sentido contrario, no apunta a dilucidar una obra específica, sino a la aplicación del método en su totalidad, hasta agotar las perspectivas; por ello, transitamos de obra en obra de nuestro canon occidental priorizando en cada momento aquella que sea más útil para aclarar el mecanismo interpretativo en juego. Semiótica, discurso postestructuralista, narratología, semántica, retórica general textual... todas son herramientas en juego para construir el aparato hermenéutico propuesto por el autor y en todas ellas el magisterio fluye generoso.

Al recopilar en una perspectiva didáctica todo el bagaje de herramientas que ha visto en funcionamiento, desde las fuentes clásicas hasta aquellas de nuestros días, el autor construye la memoria viviente de nuestro quehacer críticointerpretativo. Hermenéutica literaria está llamado a ser considerado un libro clásico para nuestros estudios literarios, esperamos lleguen otros aportes similares que nos hagan llamar a esta contribución el penúltimo clásico. Este libro es un regalo que resume una vida dedicada al conocimiento y goce de la literatura que viene de (y volverá) a las aulas.

Mallarmé dijo "Todo el mundo existe para resumirse en un libro"; Carlos García-Bedoya ha resumido su amplio y valioso magisterio en este que nos ocupa.

\section{Carlos Manuel Arámbulo López}

Universidad Científica del Sur, Lima, Perú

Contacto: carambulo@cientifica.edu.pe

https://orcid.org/0000-0002-4970-3765 